\title{
Facets of housing and housing policies in Belgium
}

\author{
Pascal De Decker
}

Received: 27 May 2008/Accepted: 27 May 2008/Published online: 1 July 2008

(C) The Author(s) 2008

\begin{abstract}
It seems that many Belgian cities are doing well. Their population is increasing, numerous urban projects are under way, and masses of construction sites testify to effective realisations. And the inner cities are swamped with tourists and visitors attracted by the historical monuments and leisure activities. Is the 21 st century indeed becoming the era of the city, as a White Book on urban policies predicts? Or is some modification of that prediction necessary? It would seem so, since the population growth is due to people coming from abroad (family reunification or formation; asylum-seekers), while at the same time the natives — as they have done since the 1960s_keep on leaving the city. So sub- and de-urbanisation has not stopped. There are even indications that it is accelerating again. In this contribution we consider why sub- and de-urbanisation, why sprawl is so obstinate, so persistent. We look at the structures behind the Belgian sprawl, seeing them as the consequence of a longstanding dialectical process of political choices and actions, cultural convictions and economic possibilities that reinforced each other in daily practice over and over again in the dominant direction.
\end{abstract}

Keywords Belgium · Home-ownership · Sprawl · Anti-urban · Housing policies · Transportation policies $\cdot$ Spatial planning

\section{Introduction. On the origins of sprawled home ownership in Belgium}

\subsection{A messy development}

Recent tidings are promising: the flight from the cities in Belgium has stopped. Their number of inhabitants is increasing and the satisfaction of city-dwellers is rising. For the first time, comprehensive spatial development plans at different governmental levels (municipalities, provinces and regions) are being made and new developments, including

P. De Decker $(\bowtie)$

University College Ghent \& Sint-Lucas School of Architecture Ghent/Brussels,

Sint Denijslaan 293, 9000 Ghent, Belgium

e-mail: pascal.de.decker@skynet.be 
public as well as private initiatives, are under construction or in the pipeline. But not only have developers rediscovered the city; private households have put their shoulders to the wheel and started to renovate old dwellings. This can-do feeling is best expressed in a White Book commissioned by the Flemish government when it declared the 21 st century to be an urban one (Boudry et al. 2003). This renewed optimism contrasts sharply with the picture drawn by Flanders' first minister for the city approximately 10 years ago. According to Peeters (1995), the cities ${ }^{1}$ had lost their glory. Of course both images are biased. Where Peeters sees only trouble and strife, the glossy magazines only depict them as bright and shining places. The cities — and especially the larger ones—still contain large poor neighbourhoods (Vandermotten et al. 2006). Outward migration is as selective as ever, channelling the more prosperous households with children to the sub- and exurban areas and the younger, alien and poor parts of the population to the city centres. And above all, as scholars recently point out, suburbanisation and urban sprawl have increased again ${ }^{2}$ (Moortgat and Vandekerckhove 2007).

If there is one concept that can capture the spatial dimension of housing in Belgium, it is 'sprawl'. Years ago, the architecture critic Nairn (quoted by De Decker et al. 1987) wrote that Belgium managed to create architecture of such splendid and full-blooded chaos that the visitor suspends all normal judgements. And Braem (quoted by De Decker et al. 1987), a modernist architect, stated that seen from an aeroplane, Belgium must look like a patchwork quilt sewn together by a lunatic from God knows what garbage, and then spurned with disdain by an invisible giant who strews about the contents of boxes of bricks. According to De Decker (2007)—who echoes the Dutch architect Weeber (1998)—Belgian people are "dwelling wild", referring to their apparently unruly urge to built what and where they want, thereby ignoring the societal and environmental consequences.

Undoubtedly, the sprawl of well equipped, often large and detached dwellings on the fringes of the cities and further in the countryside, together with clusters of poor housing in old inner-city neighbourhoods, is an important facet that one will discover when investigating housing patterns in Belgium. A second important facet is the lack of sustainable alternatives on the housing market. Belgium is, to paraphrase Saunders (1990), a nation of homeowners. But unlike many countries that recently became nations of homeowners (Doling and Ford 2007), Belgian is an old one. Already in 1960 half of the Belgian households owned their house (Goossens et al. 1991). Another difference is that Belgian levels of owner-occupation are not the result of a steep climb (as in most of the new homeownership nations) but of slow, still ongoing growth. Basically, home ownership-seen from the perspective of the occupants-is the sole sustainable housing alternative. Private renting legislation lacks everything that is needed to be a reliable alternative: rents for new leases are uncontrolled; quality rules are basic and difficult to get applied, and since there are no rent allowances, the rent-quality ratio is often questionable. Moreover, leases are insecure (e.g., De Decker 2001). As a consequence private renting is-except for a minor group of households who choose to rent-inhabited by no-choice households and starters. ${ }^{3}$ Nor is social renting an alternative: with shares between only $6 \%$ (Flanders) and $9.5 \%$ (The Brussels Capital Region) the sector hardly covers the need, implying that long waiting lists

\footnotetext{
1 Peeters is referring to the cities in Flanders, but the same is true for Wallonia and the Brussels Capital Region. See Vandermotten et al. (2006).

2 The population growth in the cities is due to a net immigration of aliens and a high birth rate among nonnationals.

3 Although there are indications that more and more households start out on the housing market as owner of a small house or flat (De Decker 2005).
} 
and long waiting times exclude social renting as a realistic alternative. No wonder that the current Flemish housing minister compares the allocation of a social rental dwelling with winning the lottery. Nevertheless, according the minister: "The possibility of renting a good house, a good flat for a price that is a third to half of elsewhere, makes a difference in the purse" (Keulen 2006-own translation).

Following from this - as Elsinga \& Winters illustrate in this special issue - it is difficult to place Belgium's housing system in a typology, which makes it an interesting case. Belgium is, to quote Nairn (quoted by De Decker et al. 1987) again, the joker in the European pack. Sprawl and home ownership are two sides of the same coin. We will briefly elaborate on this statement in the next section. In a further section, we explain the particular institutional context of a country in devolution. And finally we will introduce the different contributions to this Special Issue.

\section{The creation of a housing system}

In order to understand the development of the Belgian "sprawl/home ownership" model, we need to elaborate three structuring tracks. These may be seen as three sustainable policy lines: (a) policies to keep workers out of the cities; (b) policies to promote home ownership to discipline the masses; and (c) the very absence of a spatial planning policy facilitates sprawl.

In order to understand the development of "wild housing", we have to go back to the Industrial Revolution, which began earlier in Belgium than in most other countries on the continent. In conjunction with urbanisation, the industrialisation of the country fostered what Kesteloot (2003) calls an anti-urban attitude. Characteristic of the times, starting with the take-off of industrialisation, workers started to concentrate in the coal-mining regions of Wallonia (the axis Liege-Charleroi-Mons-North of France), in Brussels, and in a small number of cities in Flanders (e.g., Ghent, with its textile industry). This concentration threatened the (Catholic and Liberal) elites in at least two ways. First it threatened their health. In combination with the smoke from factories, the very high density of slum developments-with their small, often back-to-back hovels and open sewers-was inhuman and lethal (Van Isacker 1978), leading to epidemics on several occasions (cholera in 1832,1845 and 1866). But next to this-which would lead to the first wave of suburbanisation of the wealthy-there was also the moral current-read: a current of secularisation and the fear of social unrest and rebellion. Cities were not only dirty and unhealthy; they were also hotbeds of rebellion, culminating in deadly riots in 1886 .

\subsection{Strategy 1: avoiding urbanisation}

The elites were, given these developments, confronted with a paradox: in order to keep the people obedient and humble, the workers should stay in their villages. In order to keep the economy going, they had to go to the cities (Verleyen 2007). In order to prevent the migration of more and more people to the cities - a process that would keep on going- a double strategy was developed. The first aimed at tempering urbanisation by making the employment centres quickly and cheaply accessible. In order to increase accessibility, a very dense network of regular railway and light rail connections was constructed, being the densest of any of the industrialising countries by the end of the 19th century (S. Rowtree, 1910, quoted by Uyttenhove 1985-see Fig. 1). In order to make the journey to work affordable, a social tariff was_- "simply and brilliantly" (Verleyen 2007)—introduced in 


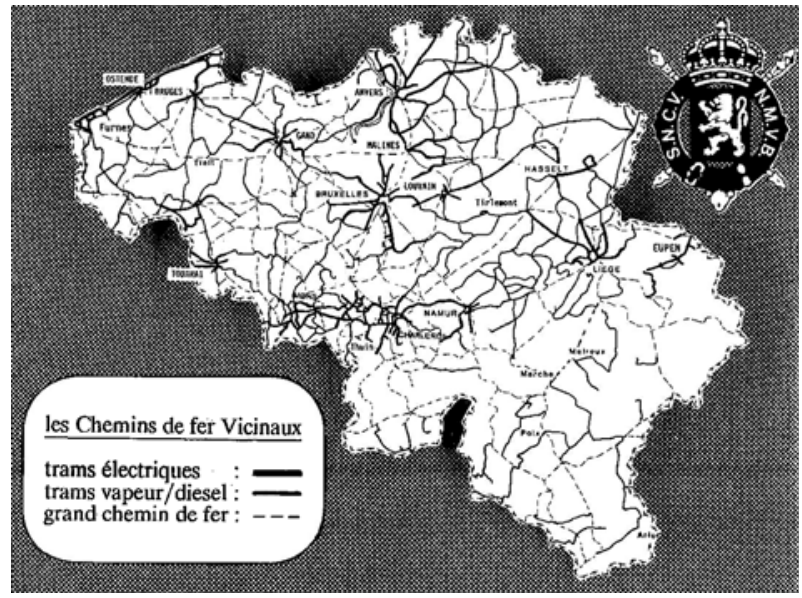

Fig. 1 The light railway tracks, 1935. Source: http://members.tripod.com/ Pdussart/carteSNCVs.jgp

1869. And it met with success, since by the 1890 s every day more than two million workers commuted to work.

The swelling anti-urban attitude was fostered and strengthened over and over again. In the first place it was given impetus by the bourgeoisie, who started to leave the city by the end of the 19th century for villas and mansions on the fringes. Thereby they introduced a dwelling model that-accompanied by the rising wealth and the development of the welfare state in the 20th century and especially after the Second World War-would be copied by more and more segments of the population and would come to dominate construction from the $1960 \mathrm{~s}$ onward. On top of that, commuting was 'socialised' (Potté 2003). In order to avoid the concentration of people in the cities, ever since 1869, social tariffs for commuting to work and school have existed. Even today-and alongside the rhetoric on urban development and renewal— this seems to be extending further. For some (e.g., civil servants) commuting by public transport recently became free of charge, and nearly all other commuters (even car users) can deduct their transport costs from their income tax. Moreover, as the railway systems went into decline after the Second World War, they were replaced by and competed with a network of buses and a dense road network. So numerous small cities, villages and hamlets became directly connected. As a consequence, no urban place of work or school area was too far away to provoke a move, since there was neither a financial nor a temporal reason for it.

\subsection{Strategy 2: promoting of home ownership}

The second strategy to counter the twin development of industrialisation-urbanisation was the stimulation of home ownership. As an offshoot of the deadly riots of 1886, in 1889 a path-breaking housing law was passed as a chapter of the first labour law. Besides the fact that the Belgian government wanted to compensate for the lack of initiative by the local authorities concerning housing for the workers, the main objective of the law was to promote home ownership via the construction of cheap dwellings, tax exemptions and cheap social loans (Smets 1977; Goossens 1982). As a bonus, owners and families who were saving for a house of their own were given an extra vote (Terhorst and Van de Ven 1997). 
The impact of this law on private house construction and "wild" building can hardly be underestimated. Although the law made it possible to establish social housing companies that construct social rental dwellings, its success was largely due to the mortgages provided by these companies. According to a Belgian representative at an international conference in Düsseldorf in 1902, this was linked to the fact that "the Belgian worker preferred to construct a new house on a parcel of his own and according to his own inspiration. In order to realise that, he opts to collect enough savings in order to bargain with a credit provider, rather than to move into an existing building" (quoted in Smets 1977-own translation).

Fundamental to the 1889 law is that it prevented the construction of large quarters for workers and fostered the dispersal of the working class. Through the individualisation of the support by giving social loans linked to savings, housing became a matter of individual initiative and do-it-yourself implementation (De Decker 1996). As a consequence, living in low densities, privatised housing, and a spatially chaotic setting gradually became normalised. The possession of a house of one's own was, since the beginning of the 20th century, part of the grammar of living (Flint and Rowlands 2003) of a normal Belgian household.

After the growth of the anti-urban attitude during the 19th century, according to Mougenot (1988), a broad consensus on the solution to the housing problem arose: individual home ownership, preferably of a single family dwelling. Different features would reinforce this, and the role of policy-makers and the government cannot be underestimated. At every moment in the past, there have been instruments, subsidies and organisations to promote home ownership. Besides the still existing tax exemptions-by far the largest subsidy (De Decker 2000) - and cheap/social loans, this concerned, in ever changing proportions, grants, premiums, social dwellings for purchase, cheap/social building parcels and rent subsidies; the purpose was often to stimulate new construction, not renovation or rehabilitation. After the introduction of a grant for new construction in 1922, it was the construction grant of 1948 that would become a tremendous success and characterise the Belgian landscape. Between 1948 and 1961 between 350,000 and 400,000 grants were allocated (Buyst 1992).

Not only did the policies targeted at individual households sustain the model; the initiative of the main housing institutions also reinforced its foundation. Classic are the actions of the still functioning Housing Fund for Large Families (Woningfonds). Starting from the observation that large families had to live in deplorable conditions, in 1928 that private company obtained governmental permission to give large families cheap(er) loans at a degressive interest rate-linked to the number of children-to large families. ${ }^{4}$ The government hoped this degressive rate would help to solve the housing problems of large families by forcing them into home ownership. Just as "model building" as the other initiatives were the construction activities of another housing institution, the National Housing Company for Small Rural Houses (NMKL) and its recognised local housing companies. Their activities concerned the construction of dwellings for sale and the purchase of cheap building plots-linked to a cheap/social loan-in the countryside or on the fringes of the cities. ${ }^{5}$ Workers, the unemployed and other asset-poor households could supplement their income though produce from their garden (growing vegetables, fruit, and raising small animals) (Goossens 1982). The foundation of the NMKL was linked to the

\footnotetext{
4 At that time a large family started from three children. Today in the Flemish region, it starts from one child.

5 Similar activities still exist in the regions of Flanders and Wallonia.
} 
crisis of the $1930 \mathrm{~s}$ and the steep rise of unemployment, leaving the unemployed wandering through the cities. In order to compensate for the risks of this vagrancy, the government wanted the unemployed workers to leave the cities for the countryside to live in their own house with a garden.

The model has another important facet. It concerns the influence in a Catholic country of the Social Doctrine of the Catholic Church as written down in the Papal Letters Rerum Novarum (1891) and Quadragesimo Anno (1931). The influence is two-pronged. In the first place, the texts advocate promoting ownership for workers. It should guarantee the emancipation of the individual in the environment of the family. The implication that ownership, because of its costs, disciplined the workers was tacitly accepted. Besides that, in the construction and consolidation phase of the model (pre-1940), the Catholic parties, who were the conservators of the model, were always members of the government and the dominant political force (which was sustained by the Christian Workers Movement, still the largest trade union in Belgium and the main promoter of the model). As a consequence of this power position, a change of path was never on the agenda. The promotion of home ownership was also sustained by the Liberal party for whom ownership is a core feature of their ideology (see, e.g., former Prime Minister Verhofstadt's pleas for 100\% ownership; Verhofstadt 2002). And recently, the (Flemish) socialist party joined the club when its chairman declared that his ideal society is one with as many owners as possible and as few tenants as possible (Stevaert 2003). In its declaration of principles in 2007 the socialist party writes: "Everybody has the right to a comfortable, qualitative and affordable dwelling. We want as many people to own their house as possible. This is the best guarantee for living well and it is the best way for pension saving" (www.s-p-a.be-own translation).

\subsection{The reality of the urban field}

The construction of the model was and is also supported by what people see in the field. For a very long time-and to some extent even today-the reality of the city is that of an antimodel, a model of negative publicity. Lots of reports, policy memoranda and popular media reportages have illustrated the lack of any alternative position for large-city neighbourhoods because of the densely built, poor-quality housing in areas with little greenery and open space. A statement by the journalist Chris De Stoop made in the year 2000 is striking: "I live now on the other side of Antwerp, in between the fields, where I raise tomatoes and cucumbers. I farm in my conservatory. I lived in the city between my 20th and 40th year of age. I'm happy about that, but now I have two children and I cannot imagine how I can raise them in the city, I grew up in the fields" (in Ghijs 2000-own translation). Concerning conditions in a Ghent neighbourhood in 1980, Pehlivan, a former senator and the first alderman in Ghent with Turkish roots, wrote: "I was confronted with inhuman conditions. In the Ossestraat people lived in medieval conditions without the most elementary hygienic amenities: no running water, no bathroom, common toilets in the streets, walls with water running down on them. It was like living in a Turkish mountain village moved to a backward neighbourhood in the city" (De Bok and Pehlivan 2003-own translation). And again some 20-30 years earlier the famous novelist L.P. Boon (1988) referred to the Ghent quarters where the workers lived in "corps of streets", where the streets have names of flowers and trees, but where "you don't see a twig, a leafor a flower" and where the people living in it never saw the tree giving its name to the street (Figs. 2 and 3).

When in the 1960s, fostered by the rising wealth and welfare state arrangements, the model took off to become mass housing, the cities were still dirty places where factories 


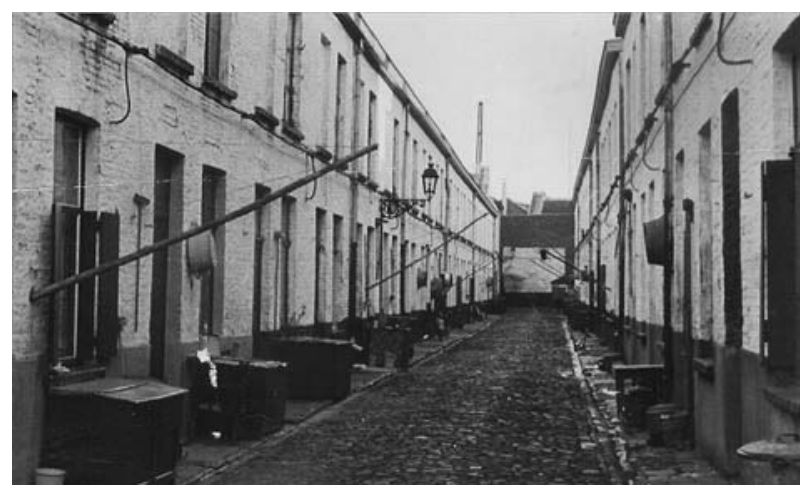

Fig. 2 Poor housing in the 19th century quarters of Ghent (around 1900)—sources: Reynebeau (2005)

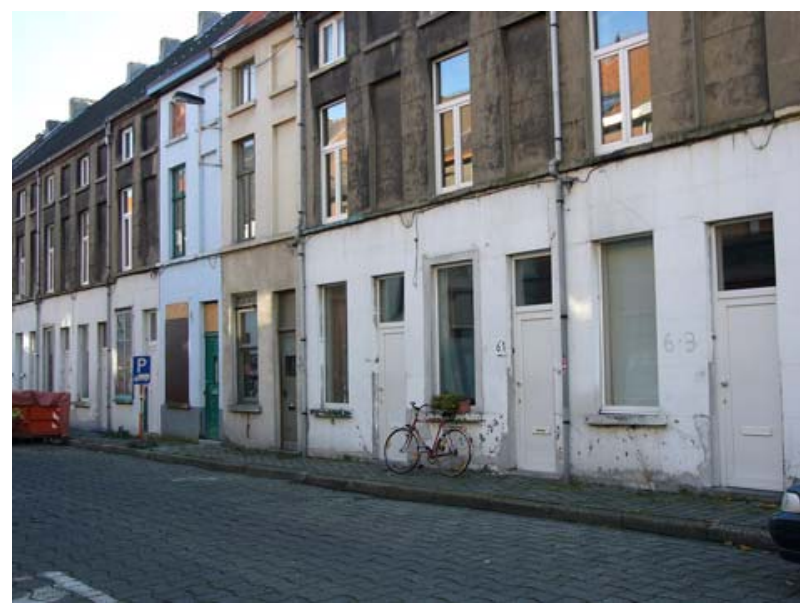

Fig. 3 Poor housing in the 19th century quarters of Ghent (2007)—own picture

and densely packed dwellings evoked disgust. In the meantime, competing with the cities for its residents (Goossens 1983), the adjacent local authorities offered lots of building plots for new construction where the single family houses arose. It is also via social imitation (Mougenot 1988) that the model is consolidated over and over again. Besides the absence of an urban renewal policy until today (De Decker 2004), it should be stressed that the examples of good housing given by the housing institution also refer to rural housing. Illustrative are the dwellings shown in Figs. 4 and 5. And even the few more collectivising initiatives built in the early days of social housing were often inspired by an idyllic rural vision (Fig. 6). Moreover, 54\% of the today social rental dwellings are single family houses (Heylen et al. 2007).

\subsection{What is not...}

In order to understand the robustness of the model, some more features have to be taken into consideration. It is not enough to look at what was and is, it is also necessary to look at 


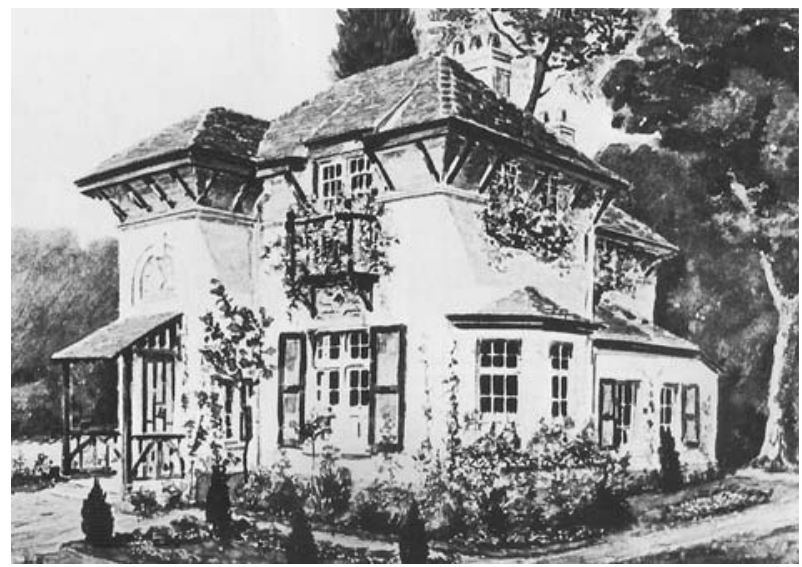

Fig. 4 Model social dwelling presented by the ASLK, the organisation responsible for financing social housing at the Brussels World Exhibition of 1910 (left)—source: Smets (1977)

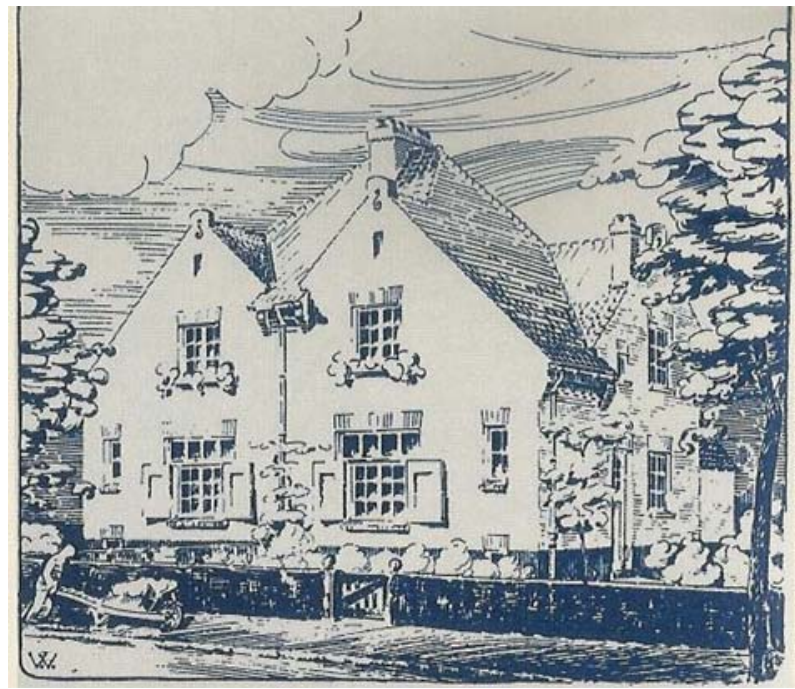

Fig. 5 Design for a social rental dwelling in Zaventem, 1921 (right)_sources: Smets (1977)

what is not: a reasonable alternative. Since the start of housing policies in Belgium, all governments have promoted one model and neglected or ignored the alternatives. In view of its low shares, social rental housing is hardly a suitable safety net, with $14.7 \%$ of the population living in poverty (Campaert 2007). Private renting was never seriously regulated (see earlier, De Decker 2001) and in periods of exuberant rent rises, this was never compensated by rent allowances. Added to that, no serious housing renewal programme was ever set up. As a consequence, in one of the most prosperous regions of the world, about $10 \%$ of the stock is still of bad quality (Vanneste et al. 2007-see further in this issue). 


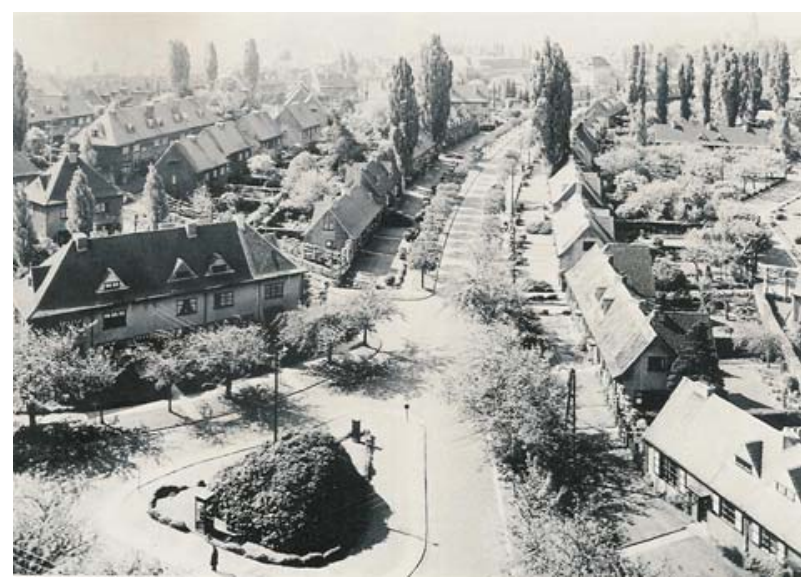

Fig. 6 Garden neighbourhood Le Logis-Floréal, 1921-1930. Source: Smets (1977)

\subsection{Strategy 3: no spatial planning}

In order to understand the social construction of "dwelling wild", we need to highlight a final piece of the foundation, being spatial planning or rather the lack of it. Fundamental is that until 1962 Belgium had no spatial planning policy. ${ }^{6}$ It is only with the 1962 Law on Spatial Planning that the arsenal of instruments-among which the building permission, the allotment permission and the spatial plans at different levels-was introduced. Crucial is that the district plans-in practice the only plans with a direct impact on the use of land-only got adopted by the end of the 1970s. This meant de facto that the post-war private house construction boom occurred almost without any spatial planning since the local authorities - which had not excelled in spatial planning - did not have a framework to evaluate the applications for permission to build or to develop the land. In the field this led to the dispersed implantation of private dwellings (Figs. 7-9), ribbon development along access roads to the cities (Fig. 10) and the unplanned, dispersed realisation of allotment schemes, the most common way to free up land for new house construction. Figure 11 shows the location of allotment schemes just after the acceptance of the 1962 Law in the period 1962-1967: the grey spots are built-up areas; the black ones are the accepted allotment schemes. The images used above could not be better illustrated.

The location of early allotment schemes not only fostered the development of sprawl but also had an important impact on the district plans in which the housing development areas are legally defined. The spread of the area allotments would determine the size of these development areas, and they would become large. At the end of the 1970s in Flanders, and dependent on the hypothesis concerning the size of the plots, between 715,000 and 914,000 plots of land for house construction were planned ${ }^{7}$ (De Decker 1993). And even today, spatial destination plans designate approximately 410,000 plots of land (VVSG 2007). Interestingly, the minister responsible for the law underpinning the district

\footnotetext{
${ }^{6}$ Contrary to, e.g., the Netherlands, where the 1901 Housing Law contained spatial planning arrangements, this was not the case with the Belgian Housing Law of 1889.

7 Between 1981 and 2005 the number of households grew in Flanders by 540,200 from 1,961,481 to 2,501,681 (Federal Administration, National Institute of Statistics).
} 
Fig. 7 Dispersed housing in the southwest of Ghent, own pictures

Fig. 8 Dispersed housing in the southwest of Ghent, own pictures
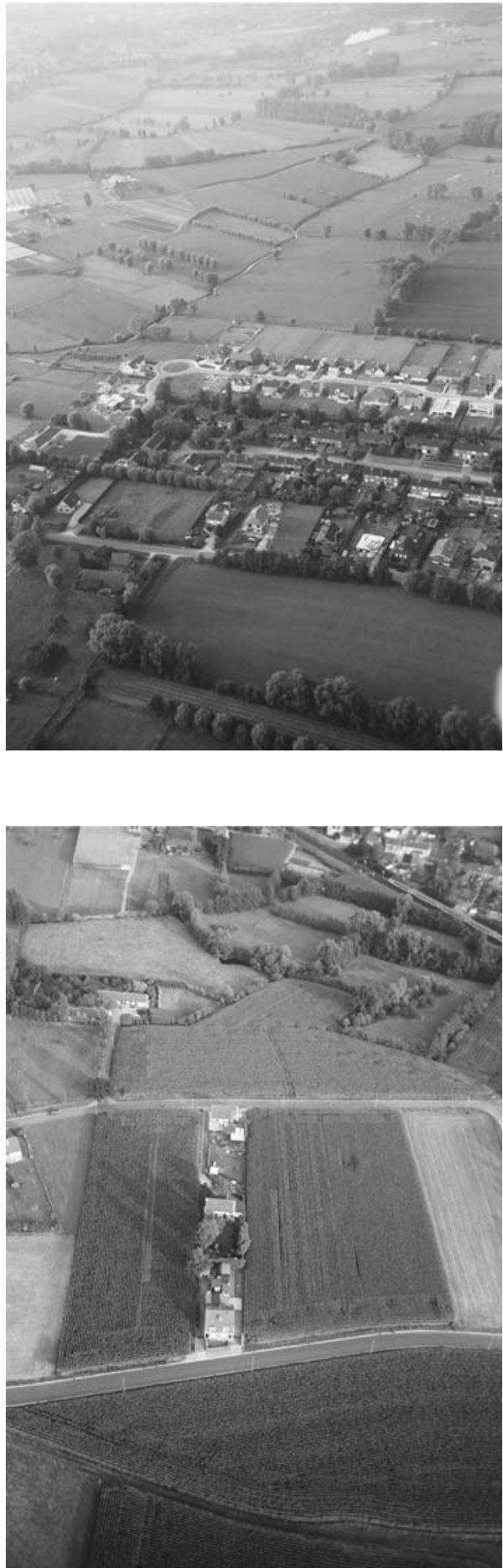
Fig. 9 Dispersed housing in the southwest of Ghent, own pictures

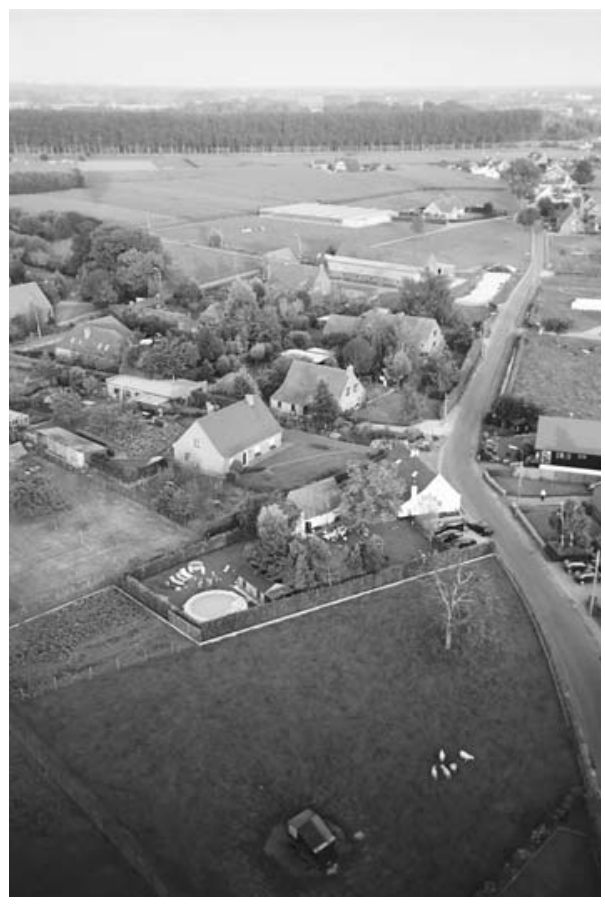

plans proposed large surface areas, assuming that a land policy would/could not emerge. Since he welcomed the idea of a house for every family, he had to prevent land prices from rising. In order to do that, the market should be ample. This- together with the location of the early allotment plans-would explain why the district zoning plans provided for such huge spaces. So, not only did the district plans come (too) late, they even fostered a further dispersal once they were operational since within the boundaries of the demarcated areas there was enough space for "wild" development.

Finally, the afore mentioned minister got it right: no land policy has been developed so far, which has led to a typical sustained pyramidal structure of land prices (Fig. 12). Urban land is expensive while non-urban land is cheap, getting cheaper the farther away from the centres it lies. Non-urban land is the roof over the Belgian "wild dwelling house". Given the easy and cheap accessibility of non-urban areas and the nature of the housing subsidies fostering new construction by individual families, families sought a housing plot ever farther away from the cities (see Vanneste et al. in this issue).

\section{Devolution through constitutional reform}

Belgium was a highly centralised country before the constitutional reforms of 1970 . The 1830 Constitution was revised only twice since its inception and both revisions involved the extension of voting rights. However, since the 1963-64 language laws Belgium has experienced five major constitutional reforms: the first in 1970, the second in 1980, the third in 1988-89, the fourth in 1993 and the fifth in 2001. These reforms have fundamentally reshuffled the institutional landscape. They resulted in the federalisation of 


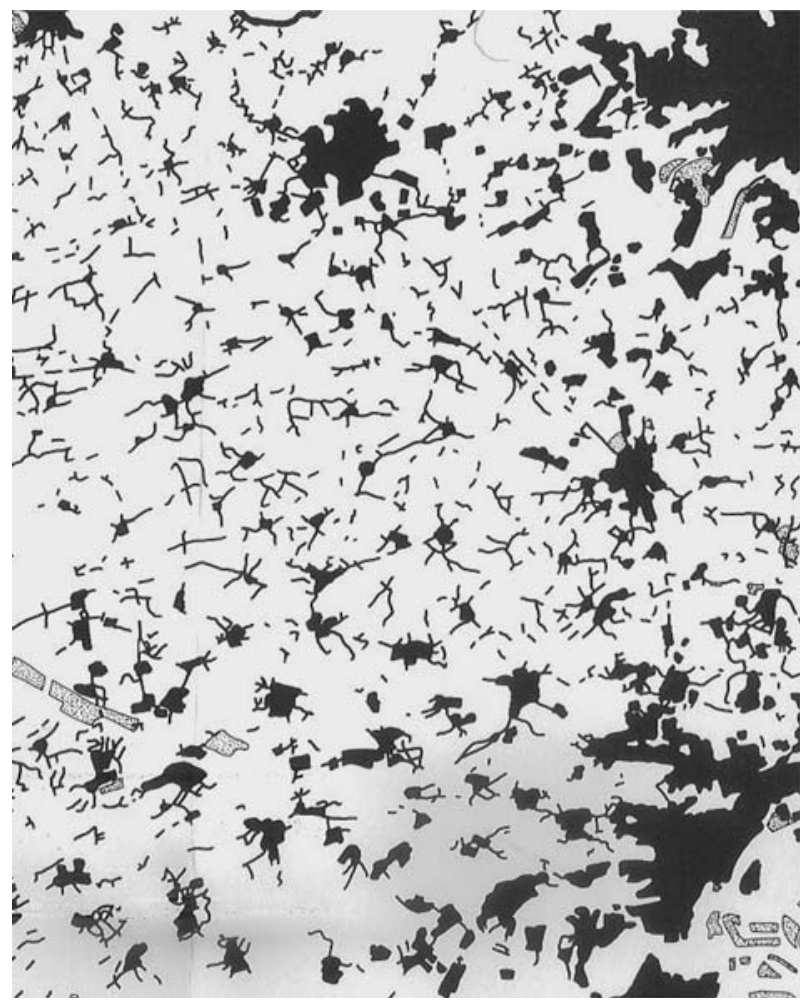

Fig. 10 Ribbon development patterns in the centre of Flanders-source: Larnoe (1993)

Belgium, bringing about a gradual devolution of powers from the federal level to the Communities and Regions. Three political, legal and cultural situations have been created:

- Four linguistic regions: the Dutch, the French and the German language regions and the bilingual region of Brussels. These regions have no political role or authority.

- Three Communities: the French, the Flemish and the German-speaking Communities. They have jurisdictional competence over personal matters such as education, culture, health care, social policy and family policy.

- Three Regions: the Walloon, the Flemish and the Brussels Capital Region. They became operational through the reforms of 1980 (Walloon and Flemish Regions) and 1989 (Brussels Capital Region). The Regions are competent for area-specific matters, such as economic policy, employment, environmental planning, housing, public works and conservation.

This complex regional and communitarian organisation has led to the creation of a complex set of institutions. At the federal level the remaining institutions are the King, the federal Parliament (the House of Representatives and the-reformed-Senate), the national government and a civil service. The federal government is largely responsible for taxation, justice, internal policy, foreign policy, defence and social security (unemployment, minimum income, health, pensions). At the level of the Communities and the Regions, each has a parliamentary assembly (called a 'Council'), a government (called an 'Executive') and a civil service. According to the system's logic, there are three Councils, being one for each Region, 


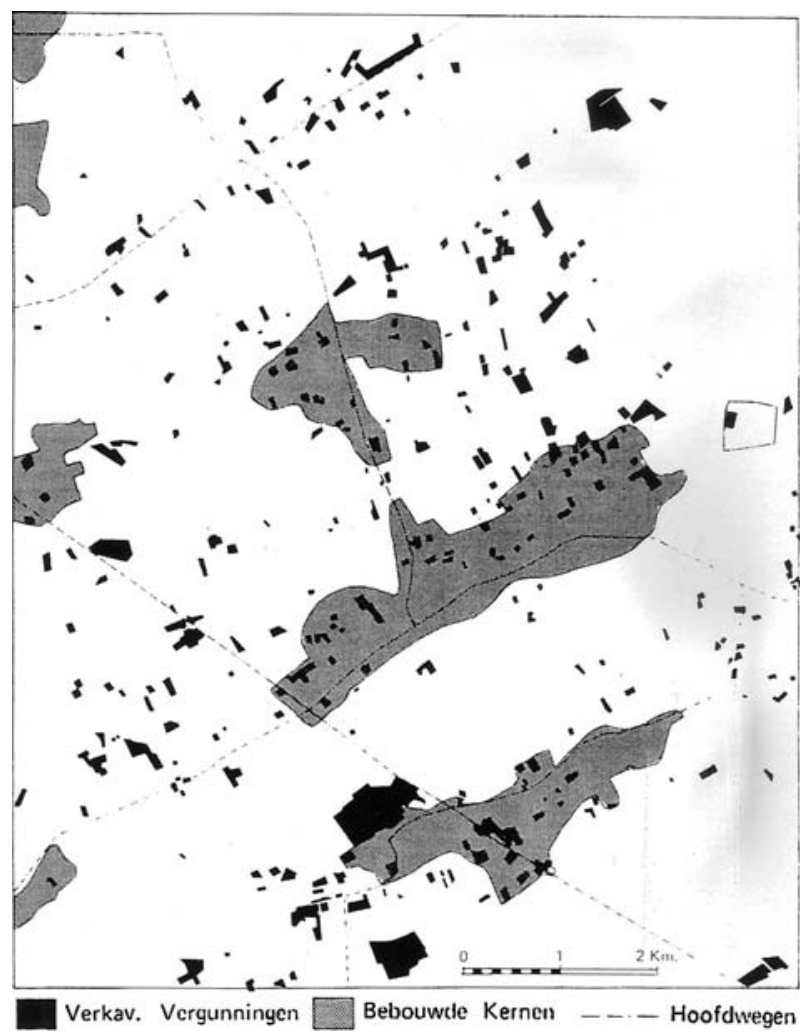

Fig. 11 Sprawl of allotment schemes, 1962-1966. The grey spots are the built-up areas, the black spots are the agreed allotment schemes-source: Van Havre (1967)

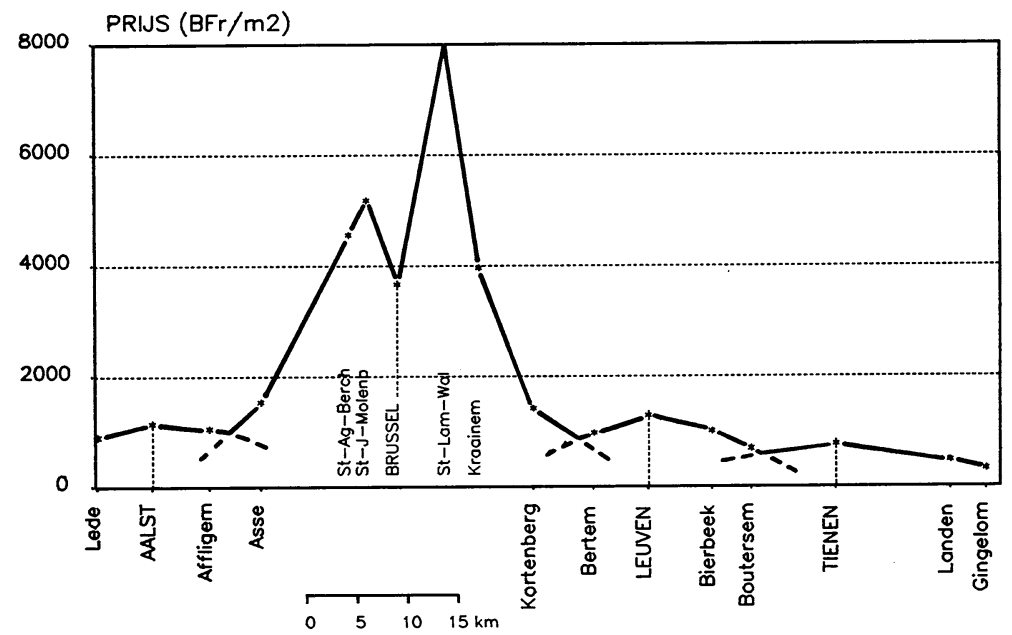

Fig. 12 Building plots, price per square metre on the cut Aalst-Brussel-Leuven-Tienen-source: Pootemans (1992) 
three more, being one for each Community, and six governments or Executives. In practice, there are eight elected assemblies, eight governments and eight administrations (or civil services). The reason is that in Flanders, the Councils and the Executives of the Region and the Community, though legally not merged, are organised and managed as one entity. This is expressed in a renaming of the Council (now Flemish Parliament) and the Executive (now Flemish government). The French-speaking community organised in the French Communal Commission promotes the interests of the French-speaking residents in Brussels. The Dutchspeaking community organised in the Dutch Communal Commission promotes the interests of the Dutch-speaking residents in Brussels. A Joint Communal Commission promotes the common interests of both groups of residents.

According to the Constitution, housing is fully the responsibility of the regions. Nevertheless, important matters like private renting and fiscal policies remain federal responsibilities. Following the federal elections of 2003-pushed by slum landlordism affecting political refugees-we have seen a modest return of the federal level on the housing scene. It should be noted that the federalisation did not lead to a divergence in regional policies (Hubeau 2000). In their legislation all three regions created the legal basis for the continuation of the role of the major institutions as well as the possibilities to keep or (re)introduce a range of incentives. On top of that, all regions created the legal basis for new institutions (e.g., social rental agencies) or new measures (e.g., on combating vacancy and slum landlordism). So the devolution of the Belgian state did not really lead to a divergence of housing policies in the three regions. On the contrary, the three regions by and large stayed on the beaten paths.

\section{This issue}

This special issue sheds light on-besides anti-urbanism, as illustrated above-some other major facets of housing in Belgium: the housing patterns, being patterns of sprawl, and housing policies, being by and large the promotion of home ownership. It presents two research articles and two text on policies and practices.

The first article sets the scene. Vanneste, Thomas \& Vanderstraeten show the spatial structure(s) of the Belgian housing stock. Using the 2001 Census, they link it to the spatial outcome of socio-economic inequalities on a (sub)regional level and to the cultural landscape. A selection of housing patterns illustrates the processes that segment the Belgian housing stock: north-south contrasts, east-west differences, centre-periphery and urban-non-urban dualities.

The second article also uses the 2001 Census. It deals with Brussels. As mentioned earlier, Belgium's central urban areas already saw their population decline before the Second World War (Vander Kerken 1976). This process has been reversed, as also the Brussels CR has recently seen a population increase. In addition, the Brussels CR, given its status as capital of Europe, is confronted with high pressure on land and buildings (for offices and for houses). Van Criekingen deals with the issue of gentrification and considers its consequences for the less prosperous inhabitants of the city. He argues that research on the socio-spatial effects of gentrification, and the issue of displacement of socially vulnerable groups in particular, needs to be re-invigorated. Looking abroad, he advocates such a research orientation in cities like Brussels, that is, outside the key metropolises of the Anglo-American world which have long dominated the gentrification literature. Issues of gentrification and displacement are approached here via a broader empirical analysis of the socio-economic profiles and destination municipalities of individuals who moved out of 
Brussels' gentrifying neighbourhoods in the early 2000s. Findings clearly indicate that highly contrasted residential mobility patterns are conflated in this set of migrants. Among them, low-status households moving presumably under some sorts of constraints-rather than by choice alone-comprise a small though tangible portion of out-movers from gentrifying neighbourhoods. These migrants relocate predominantly within the city, fuelling a mounting concentration of vulnerable groups in traditional working-class and ethnic neighbourhoods. However, longer-range migrations towards economically depressed areas outside the city are also apparent. Finally, Van Criekingen argues that these findings give a believable picture of the geography of displacement, hence adding to previous work on the migration dynamics of gentrification in contexts of market-led housing economies.

Numerous studies have analysed how household structure, position on the labour market and educational factors influence choices of housing tenure. They have shown that the probability of becoming homeowners is higher for married individuals, those in secure employment or those with a higher educational level. This contribution analyses how, despite this general model, people with low socio-economic profiles became homeowners in Brussels, especially during the eighties.

Following these articles, we present two texts dealing with policy issues. The first concerns options for social housing in Flanders, while the second highlights housing problems in the Brussels CR.

Social housing in Flanders covers a share of 5-6\% of the housing stock. This social rental sector is de facto characterised, according to Winters and Elsinga, as a safety net by some housing researchers and as a general model by others. During the nineties and the first half of this decade social housing in Flanders came under discussion. The image of social housing that dominated then was one of increasing problems with tenants and neighbourhoods (see, e.g., De Decker and Pannecoucke 2004). Raising the income limits to get a better social mix was advocated by the sector and afterwards by politicians as one of the solutions to these problems. Meanwhile, this policy would also improve the revenues of the housing associations. The political discourse, however, was very weakly supported by scientific knowledge. The contribution of Winters and Elsinga describes the current situation on the basis of the results of the 'Housing Survey 2005'. The authors use that material to position the Flemish sector in a theoretical and international perspective and then explore future policy options.

In a second text on policies, Bernard goes back to the Brussels CR. Especially due to the impoverishment of the population of the capital, combined with the increasing tendency to family separation, the need for low-income housing is constantly growing. Unfortunately, the public supply remains inadequate to absorb this demand. The Brussels authorities have started an extensive plan for the construction of 5,000 low- and middle-income units, but this plan is faced with, if not failure, at least serious problems in its realisation. But why is it so arduous to build social housing in the Brussels Capital Region? Bernard expands on this topic.

Open Access This article is distributed under the terms of the Creative Commons Attribution Noncommercial License which permits any noncommercial use, distribution, and reproduction in any medium, provided the original author(s) and source are credited.

\section{References}

Boon, L. (1988). Memoires van Boontje. Amsterdam: Arbeiderspers.

Boudry, L., Cabus, P., Corijn, E., De Rynck, F., Kesteloot, C., \& A. Loeckx (2003). De eeuw van de stad. Over stadsrepublieken en rastersteden, Witboek in opdracht van P. Van Grembergen, Vlaams Minister van Binnenlandse Aangelegenheden, Cultuur, Jeugd en Ambtenarenzaken en bevoegd voor Stedenbeleid, Ministerie van de Vlaamse Gemeenschap, Brussel. 
Buyst, E. (1992). An economic history of residential building in Belgium between 1890 and 1961, Studies in Belgian Economic History 1, Koninklijke Academie voor Wetenschappen, Letteren en Schone Kunsten van België, Brussel.

Campaert, G. (2007). Over inkomen en rondkomen. In J. Vranken (Ed.), Armoede en Sociale Uitsluiting. Jaarboek 2007 (pp. 55-70). Leuven/Voorburg: Acco.

De Bok, R. \& Pehlivan, F. (2003). Enkele reis Istanboel/Brussel, Houtekiet, Antwerpen.

De Decker, P. (1993). Ruimtelijk Structuurplan Vlaanderen. Deelproject Prognoses: Huisvesting, Eindrapport in opdracht van K.U. Gent: Leuven Research \& Development.

De Decker, P. (1996). Doe-het-zelf. Over marktgericht huisvesten in een verzorgingsstaat. Nieuw Tijdschrift voor de Volkshuisvesting, 2(6), 32-35.

De Decker, P. (2000). Who benefits from housing subsidies in Flanders, Belgium? Paper prepared for and presented at the ENHR Conference, Gälve (Zweden), June (org. European Network for Housing Research).

De Decker, P. (2001). Jammed between housing and property rights. Belgian private renting in perspective. European Journal of Housing Policy, 1(1), 17-40.

De Decker, P. (2004). De ondraaglijke lichtheid van het beleid voor de stad in Vlaanderen. Van geïndvidualiseerd woonmodel tot stedelijke crisis; een sociologische analyse ph.d in political and social sciences. Antwerp: Antwerp Unversity.

De Decker, P. (2005). Belgium. Household interview report, report for the OSIS research project (Origins of security and insecurity: The interplay of housing systems with jobs, household structures, finance and social security). Antwerpen: OASeS, Universiteit Antwerpen.

De Decker, P. (2007). De structuren van het wilde wonen in Vlaanderen, In N. Vannuffel (red), Van Christaller tot Wallerstein, Liber Amicorum Piet Saey, Nautilus Academic Books, pp. 241-258.

De Decker, P., Lammens, E., van der Sluys, P., van der Vliet, L., \& Van Severen, P. J. (1987). Flanders' urbanity; an outline. Planning Outlook, 30(2), 91-98.

De Decker, P. \& Pannecoucke, I. (2004). The creation of the incapable tenant. A preliminary assessment of the discourse on social rented housing. Journal of Housing and the Built Environment 18(4), 293-303.

Doling, J. \& Ford, J. (2007). A union of homeowners. European Journal of Housing policies, 7(2), 113-127.

Flint, J., \& Rowlands, R. (2003). Commodification, normalisation and intervention: cultural, social and symbolic capital in housing consumption and governance. Journal of Housing and the Built Environment, 18, 213-232.

Ghijs, I. (2000). Ik worstel en kom boven. Dubbelinterview met Chris de Stoop en Tom Lannoy. De Standaard Magazine, 8 Sept., pp. 9-11.

Goossens, L. (1982). Het sociaal huisvestingsbeleid in België. Een historisch-sociologische analyse van de maatschappelijke probleembehandeling op het gebied van het wonen, onuitgegeven doctoraat. KUL, Leuven: Faculteit Sociale Wetenschappen.

Goossens, L. (1983). Het sociaal huisvestingsbeleid in België sinds 1830. In G. Knops \& L. Goossens (red.) Sociaal woonbeleid (pp. 12-33). Brussel: Koning Boudewijnstichting.

Goossens, L., Noens, I., \& Maes, T. (1991). Wrikken aan wonen. Brussel: Koning Boudewijnstichting.

Heylen, K., et al. (2007). Wonen in Vlaanderen. De resultaten van de woonsurvey 2005 en de uit-wendige woningschouwing 2005, Kenniscentrum voor een Duurzaam Woonbeleid in opdracht van de Vlaamse gemeenschap, Brussel.

http://members.tripod.com/ Pdussart/carteSNCVs.jgp.

Hubeau, B. (2000) Divergentie of convergentie? Over het juridisch kader voor de sociale huisvesting in de drie gewesten in de $21^{\text {ste }}$ eeuw. Ruimte \& Planning, 20(4), 335-339.

Kesteloot, C. (2003). Verstedelijking in Vlaanderen: problemen, kansen en uitdagingen voor het beleid van de 21ste eeuw. In: Boudry et al. (eindred.), pp. 15-40.

Keulen, M. (2006). Interventie, Stuk 824 (2005-2006)-nr 5. Brussel: Vlaams Parlement.

Larnoe, G. (1993). Lintbebouwing in het Vlaamse gewest. Planologisch Nieuws, 13(3), 271-273 (+map).

Moortgat, W. \& Vandekerckhove, B. (2007). Ruimtelijke analyse van de migratie in en naar Vlaanderen. Ruimte \& Planning, 27(4).

Mougenot, C. (1988). Promoting the single-family house in Belgium: The social construction of model housing. International Journal of Urban and Regional Research, 12(4), 531-547.

Peeters, L. (1995). Voor steden en mensen, Beleidsbrief 1995. Brussel: Ministerie van de Vlaamse Gemeenschap.

Pootemans J. (1992). De prijzen van het residentiële vastgoed in Vlaanderen en Brabant anno 1990: een ruimtelijke analyse. In $\mathrm{H}$. Van der Haegen \& E. Van Hecke (Eds.), Liber Amicorum Prof. Dr. M. Goossens, Acta Geographica Lovaniensia vol. 33, p. 330

Potté, R. (2003). De weg is nog lang, interview in: Knack, 23 April, pp. 44-46.

Reynebeau, M. (2005). De Belgische geschiedenis in woord en beeld. Tielt: Lannoo. 
Saunders, P. (1990). A nation of homeowners. London: Unwin Hyman.

Smets, M. (1977). De ontwikkeling van de tuinwijkgedachte in België: Een overzicht van de Belgische volkswoningbouw 1830-1930. Brussel/Liege: Mardaga.

Smets, M. (1985a, Ed.), Resurgam. De Belgische Wederopbouw, Gemeentekrediet, Brussel.

Smets, M. (1985b). De wederopbouw als onderzoeksopgaven. In Smets (red.), pp. 9-15.

Stevaert, S. (2003). Steve op de rooster, SP*a, Brussel.

Terhorst, P. J. F. \& J. C. L. Van de Ven (1997). Fragmented Brussels and consolidated Amsterdam, Nederlandse Geografische Studies nr. 223, Amsterdam.

Uyttenhove, P. (1985). Internationale Inspanning voor een modern België, In M. Smets (Ed.), pp. 33-67.

Vander Kerken, H. (1976). Het verloren gaan van de woonfunctie in de kerngemeenten van de stedelijke agglomeraties. In G. Bekaert, B. Van Reeth, \& E. Van Broekhoven (red.): Omtrent Wonen, SESO, Antwerpen, pp. 179-231.

Vandermotten, C., Kesteloot Christian, C., et al. (2006). Dynamische analyse van de buurten in moeilijkheden in de Belgische stadsgewesten, ULB. Brussel/Leuven: KUL ICEDD.

Van Isacker, K. (1978). Mijn land in de kering 1830-1980. Deel 1/1830-1914. Antwerpen/Amsterdam: De Nederlandse Boekhandel.

Van Havre, D. (1967). Verkavelingen en bodembeleid, in: Stero, jg. 1, nr. 1, pp. 13-20.

Vanneste, D., Thomas, I., Goossens, L. m.m.v. De Decker, P., Laureys, J., Laureyssen, I., Quérriau, X., Vanderstraeten, L., \& Wevers, W. (2007). Woning en woonomgeving in België, FOD Economie, KMO, Middenstand en Energie, Algemene Directie Statistiek en Economische Informatie, Brussel.

Verhofstadt, G. (2002). De vierde golf. Antwerpen: Houtekiet.

Verleyen, M. (2007). Voorloper van de file, In Knack, 7 maart, pp. 90-91.

VVSG (2007), Bouwgronden vooral in handen van de privé-sector, VVSG-Week, nr. 38, www.vvsg.be.

Weeber, C. (1998). Het wilde wonen. Rotterdam: Uitgeverij 010. 